\title{
The influence of temporomandibular disorders in neck pain and posture.
}

\author{
Rodrigo Marcel Valentim da Silva', Franciane Batista Basilio², Sillwe Capitulino Farias Costa², \\ Francisca Sueleide de Carvalho Freitas ${ }^{2}$, Elany Pereira de Medeiros², Elaine Marques Franco de Melo², \\ Karinna Sonálya Aires da Costa ${ }^{3}$.
}

\begin{abstract}
Introduction: The temporo mandibular dysfunction is a biomechanical change in the temporomandibular joint that has a multifactorial origin. The masticatory muscles has a great relationship with the body posture through neuromuscular connections. The correct posture is maintained by a harmony in muscle mechanism involving the muscles of the head, neck and shoulder girdle. Therefore changes in these structures may lead to a postural imbalance mainly related to cranio-cervical disorders causing forward head, cervical spine rectification and asymmetric shoulders established in the ATM dysfunction patients. Objective: To investigate the influence of temporomandibular disorders in neck pain and posture as well as the incidence postural changes. Method: This is a literature review article carried in databases such as Lilacs, Scielo, Medline and Bireme. The studied period was from 2004 to 2015 were used as search terms: temporomandibular joint, the temporomendibular joint syndrome and posture. Among 21 articles initially selected by electronic search in databases, 4 were excluded for the title. We selected 17 studies for a more detailed analysis through the summary, with 3 of them deleted. The remaining 14 articles were evaluated from the text reading. Result: It can be observed that there is a relationship between TMD and postural changes, patients with this disorder have postural deviations such as forward head, increased cervical lordosis and not leveling between his shoulders. Conclusion: Postural changes may be associated with temporomandibular dysfunction, although there are few studies that address physical therapy on the conduct of temporomandibular disorders in pain and posture, we can see that physical therapy is of great importance with positive results in the lives of these individuals .
\end{abstract}

Keywords: Temporomandibular Joint, Joint Dysfunction Syndrome Temporomandibular and posture.

\section{INTRODUCTION}

Temporomandibular disorders (TMD) have a multifactorial origin, causes painful signs and symptoms affecting the stomatognathic region and adjacent structures, resulting in pain, discomfort, limitations of mandibular movement and joint sounds. In addition to an intimate influence on postural deviations of shoulders, cervical spine, head and other body segments. ${ }^{(1,2)}$

Pain as one of the main symptoms of this disorder may radiate to the temporal, frontal or occipital region, presenting itself as a headache, earache, tinnitus, toothache or a combination of these symptoms. ${ }^{(3)}$

A hypothesis about the painful symptoms of the TMD is spasm of the masticatory muscles and can be triggered by distension, muscle spasm or muscle fatigue due to the resulting muscle hyperactivity of parafunctional habits also accompanied by emotional stress. ${ }^{(3)}$

The masticatory muscles have a great relation with the body posture through neuromuscular connections. ${ }^{(2)}$ Studies suggest a correlation of cervical sensory information with afferents from the trigeminal nerve, this nerve is known to supply the orofacial region. Thus individuals with TMD may present postural changes, modifying the body biomechanics. ${ }^{(4)}$

In this context the physiotherapy may be effective treating patients with TMD, because it adopts simple, non-invasive, inexpensive and conservative procedures as treatment which will help reduce the limitations and discomfort caused by the pain, thereby improving the quality of life of these patients. Active relaxation exercises, stretching, intraoral release, TENS,

Corresponding author: Name: Rodrigo Marcel Valentim da Silva. Address: Rua Nossa Senhora de Fátima, 312b, Natal (Rio Grande do Norte), Brasil, CEP: 59030-080. Cellphone: +55 (84) 91645644. E-mail: marcelvalentim@hotmail.com.

${ }^{1}$ Doutorando da Universidade Federal do Rio Grande do Norte (UFRN), Natal (RN), Brasil. 
among others, are some features that bring great benefits to the recovery of these patients. ${ }^{(5)}$

\section{METHOD}

This is a bibliographic review using the database of Lilacs, Scielo, Medline, Bireme and PEDro. The studied period was from 2004 to 2015 . The search terms used were: temporomandibular joint, temporomandibular joint syndrome and posture. Between 21 articles initially selected by the electronic search in databases, 4 were excluded because of the title for not meeting the inclusion criteria. Of the 17 retained articles, 3 were excluded because of the abstract. The remaining 14 articles were evaluated from text reading, according to figure 1.

\section{RESULTS}

Table 1 shows the type of study and population characteristics, checking the following variables: gender, number of volunteers and age range.

Table 2 shows the intervention and the procedures performed in the different studies.

Table 3 shows the results and findings of each study.

\section{DISCUSSION}

It can be observed that there are few experimental studies that approach physical therapy in patients with temporomandibular disorder. However the studies found show clearly the efficacy of physical therapy intervention in such patients.

The realization of isometrics, assets, liabilities, relaxation and stretching exercises helps to relieve pain, increase mouth opening and improve jaw movements. A study in patients with TMD observed that performing exercises associated with the use of ultrasound and patient education was superior to the use of therapies alone, thus reducing the symptoms of these patients. ${ }^{(5)}$

Mandibular mobilization has a beneficial effect in the treatment of TMD, since it increases the synovial fluid which favors the joint lubrication, and release the disk, increasing the space, improving the joint relation and minimizing disc wear. The use of this technique relies on the fact that the joint movements eliminate soft tissue contractures, restore the muscle length, enhance the function of the articular surfaces, thus favoring a better mouth opening and promoting analgesic effect. ${ }^{(8)}$

Among the techniques used to reduce the pain symptoms of TMD patients, acupuncture is one of the resources used

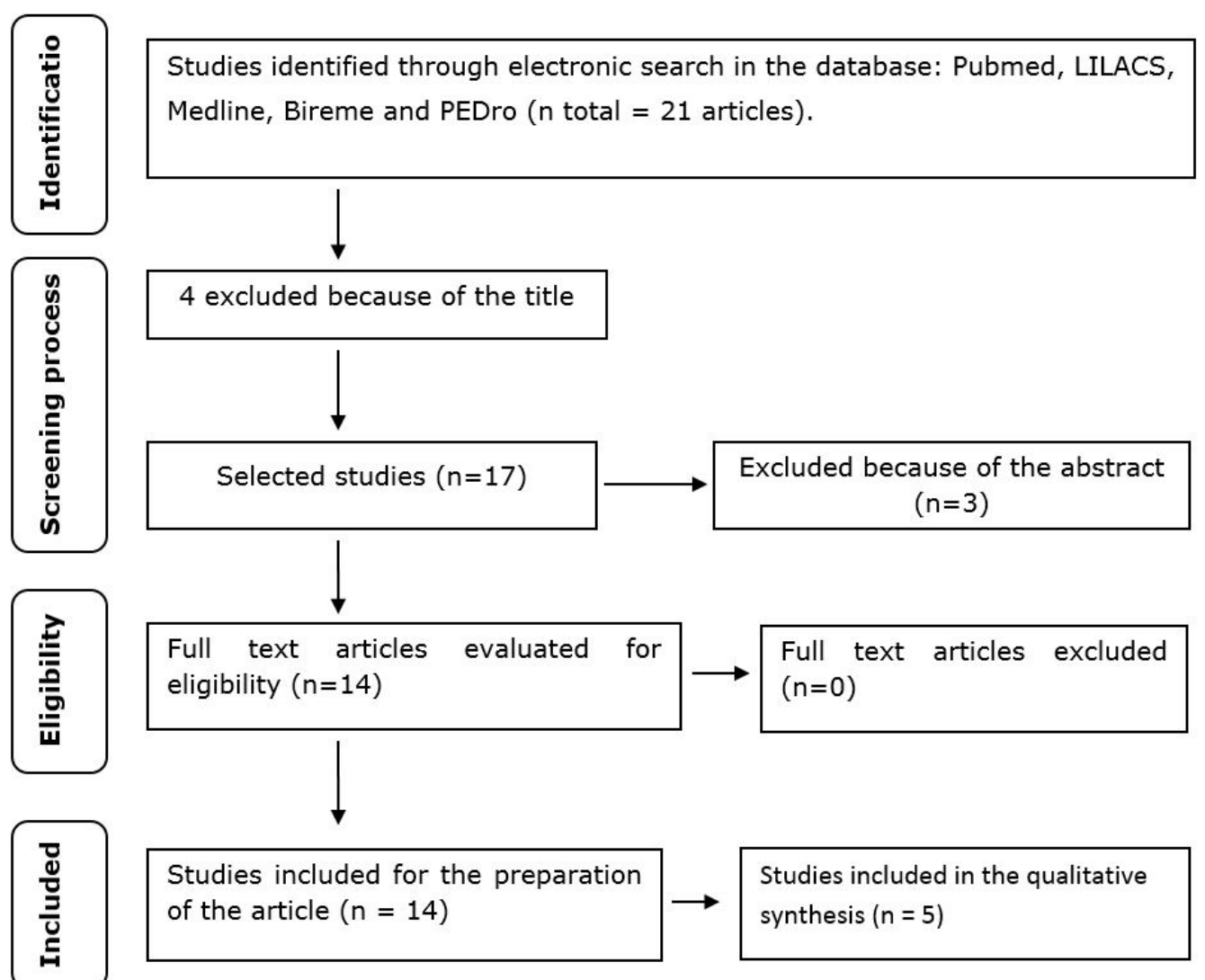

Figure 1. Search and selection of studies for the literature review. 
in treatment where this disorder is from muscular origin. A literature review showed that acupuncture promotes relief or reduction in pain intensity, decrease muscular hyperactivity of the masticatory muscles, resulting in an improvement in jaw movements. ${ }^{(9)}$

For being a complex pathology, TMD has originated several types of treatment with physical agents that associated with therapeutic approach can bring great results. Among these we can highlight the thermotherapy, electrotherapy, ultrasound, iontophoresis and laser. The low intensity laser therapy is a non-invasive modality and is used to promote relief of pain and tissue regeneration, promoting considerable comfort to the patient after application. ${ }^{(10,11,12,13)}$

TABLE 01. Population characteristics of the different studies.

\begin{tabular}{|c|c|c|c|}
\hline STUDY & TYPE OF STUDY & POPULATION & AGE RANGE \\
\hline$($ Ucar et al, 2014) & $\begin{array}{l}\text { Experimental divided randomly into } \\
\text { two groups. }\end{array}$ & 38 Volunteers & $\begin{array}{l}29 \pm 10 \text { years old (Home exercise } \\
\text { program group). } \\
27 \pm 11 \text { years old (Home exercise } \\
\text { program group associated with } \\
\text { Ultrasound). }\end{array}$ \\
\hline$($ Amaral et al, 2013) & $\begin{array}{l}\text { Experimental divided into two } \\
\text { groups: TMD group and control } \\
\text { group. }\end{array}$ & 50 volunteers & $\begin{array}{l}27.96 \pm 5.84 \text { years old (TMD group). } \\
26.52 \pm 5.24 \text { years old (Control } \\
\text { group). }\end{array}$ \\
\hline$\left(\right.$ Franco et al, 2011) ${ }^{7}$ & Case study & 1 female volunteer. & 35 years old \\
\hline (Basso et al, 2010) $^{2}$ & Experimental & 20 volunteers & Between 20 and 35 years old \\
\hline$($ Bae et al, 2013) & Experimental & 41 volunteers & Not reported \\
\hline
\end{tabular}

Source: Research data.

TABLE 02. Intervention and procedures performed in the different studies.

\begin{tabular}{|c|c|c|}
\hline STUDY & INTERVENTION & PROCEDURES \\
\hline$($ Ucar et al, 2014) & $\begin{array}{l}\text { Exercise of active and passive mouth opening, isometric } \\
\text { exercises, stretching and active resistance exercise. US ( } 3 \\
\min .0,8-1,0 \text { watt } / \mathrm{cm}^{2} \text { ). }\end{array}$ & $\begin{array}{l}\text { First Group: Two sessions per day for four weeks. Second } \\
\text { Group: Five sessions per day for four weeks. }\end{array}$ \\
\hline$\left(\right.$ Amaral et al, 2013) ${ }^{6}$ & $\begin{array}{l}\text { Nonspecific mandibular mobilization (small degree) } \\
\text { intermittent for } 1 \text { minute with } 5 \text { repetitions. }\end{array}$ & MMI for one minute with 5 replicates. \\
\hline$\left(\right.$ Franco et al, 2011) ${ }^{7}$ & $\begin{array}{l}\text { Passive stretching the trapezius and sternocleidomastoid } \\
\text { muscles, low intensity laser }\left(4 \mathrm{~J} / \mathrm{cm}^{2} \text { in joint area punctually }\right. \\
\text { and } 8 \mathrm{~J} / \mathrm{cm}^{2} \text { in the muscular area punctual and scanning, with } \\
\text { pulsatile mode } 1 \text { minute per point) and facial relaxation. }\end{array}$ & 10 sessions once a week. \\
\hline$\left(\right.$ Basso et al, 2010) ${ }^{2}$ & $\begin{array}{l}45 \text { minutes of RPG adopting two positions per therapy } \\
\text { session. }\end{array}$ & 10 RPG sessions once a week. \\
\hline$\left(\right.$ Bae et al, 2013) ${ }^{8}$ & Free active exercise and muscle relaxation exercise. & 3 sessions per day for 4 weeks. \\
\hline
\end{tabular}

TABLE 03. Results and conclusions of the studies.

\begin{tabular}{|c|c|c|}
\hline STUDY & RESULTS & CONCLUSION \\
\hline$($ Ucar et al, 2014) & $\begin{array}{l}\text { Pain decreased in both groups resulting in increased mouth } \\
\text { opening. }\end{array}$ & $\begin{array}{l}\text { The use of US associated with the home exercise program } \\
\text { has greater efficacy than the single therapy, reducing the } \\
\text { symptoms of patients with TMD. }\end{array}$ \\
\hline$\left(\right.$ Amaral et al, 2013) ${ }^{6}$ & $\begin{array}{l}\text { Immediate improvement of postural control in individuals } \\
\text { with TMD. }\end{array}$ & $\begin{array}{l}\text { Further studies are needed to understand the action of non- } \\
\text { specific mandibular mobilization on postural control. }\end{array}$ \\
\hline$\left(\right.$ Franco et al, 2011) ${ }^{7}$ & $\begin{array}{l}\text { Reduction of pain sensation, as well as decreased muscle } \\
\text { tension reported by the patient. }\end{array}$ & $\begin{array}{l}\text { Further studies are needed to verify the effects of other } \\
\text { physical therapy programs as well as their interaction with } \\
\text { other treatment modalities. }\end{array}$ \\
\hline$\left(\right.$ Basso et al, 2010) ${ }^{2}$ & $\begin{array}{l}\text { There was a reduction of disability and chronic pain } \\
\text { intensity, improvement of non-specific physical symptoms } \\
\text { and depression, improved alignment of the shoulder blades, } \\
\text { acromion and ASIS, symmetry and angles of the lower limbs } \\
\text { and head position. }\end{array}$ & $\begin{array}{l}\text { Treatment with RPG promoted an improvement of physical } \\
\text { and psychological symptoms in patients with TMD. Besides } \\
\text { the body alignment and symmetry. }\end{array}$ \\
\hline$\left(\right.$ Bae et al, 2013) ${ }^{8}$ & $\begin{array}{l}\text { There was a reduction in pain intensity and deviation } \\
\text { articulate. }\end{array}$ & $\begin{array}{l}\text { It was observed that the free active exercise and muscle } \\
\text { relaxation exercise are effective in reducing the intensity of } \\
\text { pain, and decreased mandibular movement limitation. }\end{array}$ \\
\hline
\end{tabular}


It is suggested through this research, new experimental studies to clarify the importance of physiotherapy as well as their different methods in the treatment of patients with TMD.

\section{CONCLUSION}

It can be seen that the temporomandibular changes may influence the body alignment of patients, increased pain symptoms, thus making difficult the quality of life of these individuals. Although there are few studies that approach the physical therapy conduct on temporomandibular disorders in pain and posture, we can see that physical therapy is very important obtaining positive results in the lives of these individuals.

\section{AUTHOR'S CONTRIBUTIONS}

RMVS: Author advisor and creator of the article, responsible for reviewing and textual organization; FBB : Author responsible for searching articles in the database and text writing; SCFC: Author responsible for searching articles in the database and text writing; FSCF: Author responsible for searching articles in the database and text writing; EPM: Author responsible for searching articles in the database and text writing; EMFM: Author responsible for searching articles in the database and text writing; KSAC: Author specialist and responsible for the final scientific review of the work, collaborating with lead author on work orientation.

\section{CONFLICTS OF INTEREST}

The authors declare that they have no conflicts of interest in the research.

\section{AUTHOR DETAILS}

${ }^{2}$ Graduandos do Curso de Fisioterapia da Faculdade Maurício de Nassau (FMN), Natal (RN), Brasil.

${ }^{3}$ Mestranda em Fisioterapia pela Universidade Federal do Rio Grande do Norte. Especialização em Fisioterapia Traumato-Ortopédica e Desportiva pela UFRN, Natal(RN), Brasil.

\section{REFERENCES}

1. Strini PJSA, Sousa GC, Júnior RB, Strini PJSA, Neto AJF. Alterações biomecânicas em pacientes portadores de Disfunção Temporomandibular antes e após o uso de dispositivos oclusais. Revista Odonto. 2009;17(33):4247.
2. Basso D, Corrêa E, silva AM. Efeito da reeducação postural global no alinhamento corporal e nas condições clínicas de indivíduos com disfunção temporomandibular associada a desvios posturais. Fisioterapia e Pesquisa. 2010;17(1):63-68.

3. Amantéa DV, Novaes AP, Campolongo GD, Barros TP. A importância da avaliação postural no paciente com disfunção da articulação temporomandibular. Acta Ortop Bras. 2004;12(3):155-159.

4. Weber P, Corrêa ECR, Ferreira FS, Soares JC, Bolzan GP, Silva AM T. Frequência de sinais e sintomas de disfunção cervical em indivíduos com disfunção temporomandibular. J Soc Bras Fonoaudiol. 2012;24(2):134-9.

5. Ucar, Mehmet, et al. Effectiveness of a home exercise program in combination with ultrasound therapy for temporomandibular joint disorders. Journal of physical therapy Science. 2014;26(12):1847-1849.

6. Amaral AP, Politti F, Hage YE, Arruda EEC, Amorin CF, Gonzalez DAB. Immediate effect of nonspecific mandibular mobilization on postural control in subjects with temporomandibular disorder: a single-blind, randomized, controlled clinical trial. Braz J Phys Ther. 2013 MarApr;17(2):121-127.

7. Franco AL, Zamperini CA, Salata DC, Silva EC, Júnior WA, Camparis CM. Fisioterapia no tratamento da dor orofacial de pacientes com disfunção temporomandibular crônica. Revista Cubana de Estomatologia. 2011:48(1)56-61.

8. Bae Y, Park Y. The Effect of Relaxation Exercises for the MasticatorMuscles on Temporomandibular Joint Dysfunction (TMD). J Phys T her Sci. 2013;25(5):583-586

9. Porporatti AL, Costa YM, Barbosa JS, Bonjardim RL, Conti PCR. Protocolos de acupuntura para o tratamento da disfunção temporomandibular. Rev Dor. 2015 jan-mar;16(1):53-59.

10. Moraes AR, Sanches ML, Ribeiro EC, Guimarães AS. Therapeutic exercises for the control of temporomandibular disorders. Dental Press J Orthod. 2013 Sept-Oct;18(5):134-139.

11. Chang WD, Lee CL, Lin HY, Hsu YC, Wang CJ, Lai PT. A Meta-analysis of Clinical Effects of Low-level Laser Therapy on Temporomandibular Joint Pain. Journal of physical therapy science .2014;26(8):1297-1300.

12. Maluf, SA. Efeito da reeducação postural global e do alongamento estático segmentar em portadoras de disfunção temporomandibular: um estudo comparativo. 2006. Tese de Doutorado. Universidade de São Paulo.

13. Assis TO, Soares MS, Victor MM. O uso do laser na reabilitação das desordens temporomandibulares. Fisioter. Mov. 2012;25(2):453-459. 